\title{
Immunostimulant Activity of Neem Leaf (A. indica A. Juss) Ethanol Fraction on Tilapia (Oreochromis niloticus)
}

\author{
Rika Putri ${ }^{*}$, Sri Andayani ${ }^{2}$, Ating Yuniarti ${ }^{2}$ \\ ${ }^{1}$ Master Program of Aquaculture, Faculty of Fisheries and Marine Sciences, University of Brawijaya, Malang, Indonesia \\ ${ }^{2}$ Department of Aquatic Resources Management, Faculty of Fisheries and Marine Sciences, University of Brawijaya, \\ Malang, Indonesia
}

\begin{abstract}
Intensive cultivation of Tilapia with high stock density and continuous artificial feeding will decrease the water quality and increase the growth of pathogenic bacteria. That situation led to the fish stressed so that the fish become the target of bacterial pathogen attacks. Alternatively, the environmental friendly treatment using herbal immunostimulant to solve that problem is required. The herbal in this study used neem leaf (Azadirachta indica A. Juss). The aim of this study was to evaluate ethanol fraction of neem leaf on immunostimulant activity of Oreochromis niloticus. In this study, the extraction method used maceration. Fractionation methods were using Thin Layer Chromatography (TLC) and Column Chromatography (CC). The biological component was analyzed using Phytochemical, FTIR and GC-MS methods. TLC test showed that ethyl acetate: $n$-hexane $(1: 1, v / v)$ result in brightest luminescence colors on the plates of silica gel under UV light $(365 \mathrm{~nm})$. The chromatography column from the ethanol extract of neem leaf (A. indica A. Juss) showed that separation of the fraction was done based on the formation of color, which obtained 5 (five) types of fractions. The results of the phytochemical test for the fraction 4 of neem leaf contains two compounds, i.e. flavonoids $(+)$ and triterpenoids (++). The FTIR test showed that fraction 4 of neem leaves contain a class of terpenoid and flavonoid compounds. GCMS test results on fraction 4 of the neem leaves (A. indica A. Juss) obtained the high peak, which has 4 terpenoid compounds, 1 compound of flavonoid, and 1 type of lauric acid. The total leukocyte of the fish test increased after treated with fraction 4 of neem leaf (A. indica A. Juss) compared with control on day 7 after injection, i.e. 25.29 x $10^{4}$ cells. $\mathrm{mL}^{-1}$.
\end{abstract}

Keywords: fraction, leukocyte, Neem Leaves, Tilapia, Phytochemicals.

\section{INTRODUCTION}

Production targets of tilapia fish are still below the expectation. Production target of the fish at 2016 was 1,882,200 tons while it only realized for $1,187,812$ tons, and the target until 2019 is $2,500,600$ tons.year $^{-1}$ [1]. To meet the target of production, cultivation was done intensively with the application of high stock density and artificial feeding continuously. As the effects, the quality of culture media will decrease due to the accumulation of organic material on the bottom of the ponds, which is favorable for the growth of pathogenic bacteria. With the bad condition of the cultivation media, the fish become stress so that the fish become the target of bacterial pathogen attacks that grow fast in the maintenance media resulting in the failure for reaching the production target $[2,3,4]$.

Treatment is the last alternative in cultivation activities. Thus before the fish attacked by the disease, the maintenance activities were given immunostimulants with the aim to increase the

\footnotetext{
* Correspondence address:

Rika Putri

Email : rikaputri_bppptegal@yahoo.com

Address : Faculty of Fisheries and Marine Sciences, University of Brawijaya, Veteran Malang 65145.
}

fish body's endurance if there is a situation that exceeds the normal limit of the environment. Alternative ingredients that are environmentally friendly and safe for health for immunostimulants are using plant herbal ingredients [2,59].

One of the potential herbal ingredients as an immunostimulant for fish is neem leaves. This is because neem leaves have been widely used to overcome the attack of pathogenic bacteria. Neem leaves are used as an antimicrobial because the extract of neem leaf can inhibit the growth of pathogenic bacteria both for grampositive and gram-negative bacteria $[10,11,12]$. Terpenoids or triterpenoids increase the total leukocytes of carp that attacked by Koi Herpes Virus (KHV) virus as a body defense because terpenoids have inhibitory activity against bacteria, fungi, virus, and protozoa [13]. The increase in total leukocytes in the fraction-4 treatment of the neem leaves makes the immune response more readily available to detect any attack of foreign substances entering the fish body. An increase in the number of leukocytes will make the phagocytosis process in the antigen will be better and increased the antibodies [14]. 
There is an immunomodulatory effect of neem leaf ( $A$. indica $A$. Juss) ethanol extract on the peritoneal macrophage cell number in mouse-induced BCG vaccine in which macrophages are innate immunity that serves as an initial defense against infection by phagocytosis process. It also plays an important role as the Antigen Presenting Cell (APC) that initiates and directs immunity to the cellular immune system [15]. Based on these facts in the framework of the cultivation development activities, especially for tilapia, it is necessary to evaluate the ethanol fraction of neem leaf ( $A$. indica A. Juss) on immunostimulant activity of tilapia Oreochromis niloticus.

\section{MATERIAL AND METHOD}

\section{Flouring and Extraction}

Flouring done by grind $100 \mathrm{~g}$ of neem leaf $(A$. indica A. Juss) shade-dried. The extraction was performed by maceration method for once. Total of 100 grams of neem leaf flour soaked with ethanol solvent for $2 \times 24$ hours and stirred every 4 hours, and the ratio of the material to the solvent was $1: 3, \mathrm{~b} / \mathrm{v}$ [16].

\section{Fractionation}

Fractionation characterization of neem leaf ethanol extract was analyzed by Thin Layer Chromatography (TLC) and Column Chromatography (CC) [17]. TLC analysis was performed to determine the ratio of solvent (eluent) which can draw the active ingredient compound of the extract to be performed on CC. The TLC analysis utilized a silica gel phase. The silica gel with a mobile phase comparison n-hexane: ethyl acetate $(15: 1,5: 1,9: 1,1: 1 ; \mathrm{v} / \mathrm{v})$ and chloroform: methanol $(1: 1 ; v / v)$. The action steps of TLC Analysis are as follows:

- TLC plate cut as needed with the width of 1 $\mathrm{cm}$ and height $10 \mathrm{~cm}$, at the top of the limit using a thin pencil $0.5 \mathrm{~cm}$ and the bottom 1 $\mathrm{cm}$, at the bottom of the fitting middle given the point as a midpoint and then the plate is inserted into the oven with temperature of $100-120^{\circ} \mathrm{C}$ about \pm 15 minutes to evaporate the water content;

- The extract is dissolved (ethanol) sufficiently. Then taken $\pm 5 \mu \mathrm{L}$ with microsyringe and bottle on TLC plate $1 \mathrm{~cm}$ from the lower edge with $5 \mathrm{~mm}$ diameter 20 times the bottle;

- TLC plates inserted upright into $250 \mathrm{~mL}$ chamber containing $\pm 10 \mathrm{~mL}$ eluent solvent then covered with cling wrap to avoid evaporation;
- If the eluent has reached the upper limit then the TLC plate is taken with tweezers. The appearance of the stain used is ultraviolet (UV) rays. When irradiated with UV distillation (254 nm) and distant UV (366 nm), then Rf value is calculated for polyphenol isolation (tannin) in column chromatography according to Retardation factor ( $\mathrm{Rf}$ ) value on TLC plate.

Column chromatography is the second stage in the fractionation process after thin layer chromatography (TLC). Liquid-solid adsorption chromatography based on the packing of a column with absorbent of silica gel, and neem leaf extract ( $A$. indica Juss) in elution with a solvent, i.e. ethyl acetate: n-hexane (1:1). It is based on the gravitational flow through the column, where the gravitational force push the solution down and through the column. The steps of Column Chromatography are as follows:

- Weigh $20 \mathrm{~g}$ of silica gel G60, then put in the oven with temperature $100^{\circ} \mathrm{C} \pm 15$ minutes then put in distillation until cool;

- Silica gel G60 suspended into the $n$-hexane motion phase: ethyl acetate $(1: 1, \mathrm{v} / \mathrm{v}) \pm 100$ $\mathrm{mL}$ and stirred with a magnetic stirrer for 1 hour so that when the silica gel is inserted the column not cracked;

- At the bottom of the column (above the valve of the column) is filled with glass wool as a silica holder, silica is inserted slowly. To avoid the breakage of silica in the column, shaking and suspending until the silica compaction has been established for \pm 12 hours (in the column there must be eluent);

- Weigh the extract as much as $1 \mathrm{~g}$ and dissolve it in $2 \mathrm{~mL}$ eluent, eluent in the column is removed until it remained $0.5 \mathrm{~cm}$ above silica then the dissolved extract is slowly inserted in the column and tap down the column in the open position;

- If the liquid extract in the column is running low do gradual addition of eluent;

- Separate fractions formed based on the color difference. The fractionation results are accommodated in different glass bottles according to the fraction color difference. The resulting fractional was arranged in order to obtain the fraction in a dry state fraction, concentrated in nitrogen evaporator at a temperature of $40-45^{\circ} \mathrm{C}$. The fraction is ready for further testing.

\section{Phytochemical Test and FTIR Analysis}

The phytochemical test based on Harbone method [18]. The available composition of the 
fraction obtained from Column Chromatography (CC) analysis. In phytochemical tests, there are flavonoids, alkaloids, tannins, terpenoids, and saponins. Phytochemical identification was performed on candidate of neem leaf ethanol fraction ( $A$. indica $A$. Juss) using Harborne method [18].

\section{GC-MS Analysis}

The candidate of neem leaf fraction ( $A$. indica A. Juss) is best analyzed by Gas ChromatographyMass Spectrometry (GC-MS) to know the compounds in the fraction. The GC-MS specification used is Gas chromatogram-HP 6890, equipped with capillary model of Agilent 19091 S-433 HP-5 MS (5\% Phenyl Methyl Siloxane), 250 $(\mu \mathrm{m})$ in diameter, $0.25(\mu \mathrm{m})$ thickness and $30 \mathrm{~m}$ capillary length with a flow rate of $1 \mathrm{~mL}$. $\mathrm{min}^{-1}$. Set the oven temperature to $80^{\circ} \mathrm{C} \cdot \mathrm{min}^{-1}-325^{\circ} \mathrm{C}$ per 15 minutes. The carrier gas is helium with a flow rate of $19.9 \mathrm{~mL} \cdot \mathrm{min}^{-1}$ with a pressure of $9.32 \mathrm{psi}$. The injector temperature is $300^{\circ} \mathrm{C}$.

\section{Treatment}

Treatment with ethanol fraction of neem leaf by injection intraperitoneal consists of 2 phase. Phase 1, with a dose of $25 \mathrm{ppm}$ done to determine the best fraction that can increase the number of leukocytes and erythrocytes of tilapia.

Phase 2, fish treated with the best fraction of neem leaf base on phase 1 with doses of $0 \mathrm{ppm}$, $75 \mathrm{ppm}, 100 \mathrm{ppm}$ and $125 \mathrm{ppm}$, with the espectation it can increase the number of leucocytes and erythrocytes of tilapia. Blood sampling is done at the beginning of maintenance (day 0) as data before treatment, day 3 and day 7 after injection.

\section{RESULT AND DISCUSSION}

\section{Thin Layer Chromatography Analysis (TLC)}

Eluent determination on Thin Layer Chromatography (TLC) was performed by experiment. It was conducted by combining some solvents which can produce the most color sparking in the stationary phase of silica gel plate 60F254 [18,19] seen in Figure 1.

TLC analysis is the first step in the fractionation process because it is the stage of determining eluent that can produce fractions of the tested extract. TLC analysis step is very important in relation to the isolation of smallscale pure compounds to be produced. The more precisely the solvent-solvent mixtures by virtue, the better the pure compounds can be isolated. Thus, to obtain the pure compound of the fractionation process, TLC analysis was done to determine the best eluent [19].

Based on the results of the TLC analysis on the solvent ratio, the eluent which is capable of producing the most color sparks in the 60F 254 silica gel plates (Fig. 2) irradiated by UV rays ( 365 $\mathrm{nm}$ ) is the mixing of the ethyl acetate solvent: $\mathrm{n}$ hexane $(1: 1, v / v)$. So, this yield is called fraction of ethyl acetate: $n$-hexane.

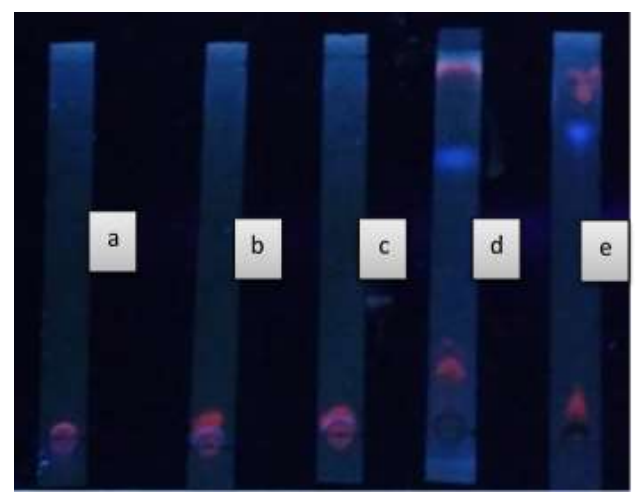

Figure 1. Thin Layer Chromatography (TLC) Analysis for Eluent Determination. Description: $\mathrm{a}=\mathrm{N}$-Hexane : Ethyl Acetate $(15: 1)$, $\mathrm{b}=\mathrm{N}$-Hexane : Ethyl Acetate $(5: 1)$ $\mathrm{c}=\mathrm{N}$-Hexane: Ethyl Acetate $(9: 1)$ $\mathrm{d}=\mathrm{N}$-Hexane : Ethyl Acetate $(1: 1)$ $\mathrm{e}=$ Chloroform : Metanol $(1: 1)$.

\section{Column Chromatography}

Column chromatography was performed to produce an abundant amount of ethanol leaf fraction using eluent obtained from the Thin Layer Chromatography (TLC) test, i.e. eluent ethyl acetate: $n$-hexane $(1: 1 ; v / v)$ as the mobile phase and the stationary phase using silica gel powder 60F254. The result of column chromatography (CC) of neem leaves ( $A$. indica $A$. Juss) ethanol fraction is seen based on the formation of color. The number of fraction of neem leaf ethanol seen from the formation of color obtained 5 (five) kinds of fraction/color (Fig. 2).

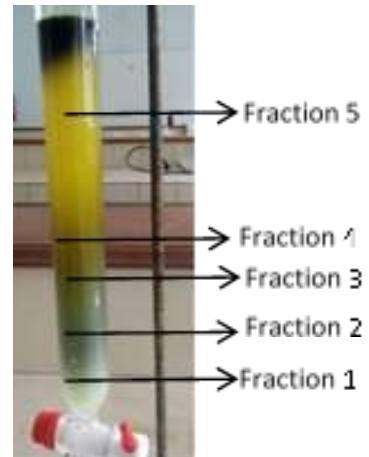

Figure 2. Column Chromatography (CC) Analysis of the Neem Leaf Ethanol Extract (A. indica A. Juss) 


\section{Ethanol Fraction Test of Neem Leaf on Tilapia Fish Leukocyte Response}

The neem leaf fraction test (A. indica A. Juss) was carried out to extract one of the best fractions of the 5 fraction types resulting from Column Chromatography (CC). The CC analysis obtained by referring to the In Vivo nonsteroidal non-specific immune respiration (leukocytes) of tilapia (O. niloticus). The result of the determination of the fraction from neem leaf $(A$. indica A. Juss) is shown in Table 1.

Table 1. Leukocyte Response (O. niloticus) againts neem leaf extract ( $A$. indica $A$. Juss)

\begin{tabular}{|c|c|c|}
\hline \multirow{2}{*}{ Fraction } & \multicolumn{2}{|c|}{ Leukocyte response $\left(\times 10^{4}\right.$ cell. $\left.\mathrm{mL}^{-1}\right)$} \\
\hline & Day-3 & Day-7 \\
\hline 1 & $15.83 \pm 0.45^{b}$ & $16.25 \pm 1.71^{b}$ \\
\hline 2 & $15.30 \pm 0.59^{b}$ & $15.82 \pm 0.90^{\mathrm{b}}$ \\
\hline 3 & $17.15 \pm 0.25^{c}$ & $17.93 \pm 0.15^{b}$ \\
\hline 4 & $24.09 \pm 1.35^{d}$ & $25.29 \pm 1.21^{c}$ \\
\hline 5 & $15.33 \pm 0.43^{b}$ & $16.44 \pm 0.20^{b}$ \\
\hline Control & $10.01 \pm 0.26^{\mathrm{a}}$ & $10.42 \pm 0.18^{a}$ \\
\hline
\end{tabular}

Notes: Day - is after injected by neem leaves fraction

From the observation of tilapia (O. niloticus) leucocytes, the fraction 4 was significantly different from the number of produced leukocytes compared to the other fractions and control, where for the leukocyte count of fraction 4 on day 7 after injection was $25.29 \times 10^{4}$ cells. $\mathrm{mL}^{-1}$. The high value of leukocytes in fish exposed to fraction 4 may be due to fraction 4 contained antigen material that can affect the leukocytes of the test fish. Increased number of leukocytes in fish due to exposure of a substance indicates that the fish responds to protect the body against incoming foreign matter [21]. Therefore, fraction 4 is the best candidate fraction for testing the non-specific immune response of tilapia (O. niloticus) at the next stage.

\section{Fraction-4 on Leukocyte}

The results of observation on leukocyte values in tilapia were significantly different (Table 2) between fish treated with fractional doses of Fraction-4 neem leaf $(75,100$ and $125 \mathrm{ppm})$ with Control (0 ppm or without treatment). At the beginning of the treatment, the leukocyte content at each concentration increased as the given fraction concentration was also increased, compared to the control. Increasing number of leukocytes with the fraction-4 neem leaf is suspected because of the terpenoid compounds. Terpenoid is secondary metabolites composed by isoprene structure that is good for the health.
The increase of leukocyte value by giving fraction-4 neem leaves make the immune response more ready to detect any foreign body attack that enter into the fish body. An increase in the number of leukocytes will make the phagocytosis process in the antigen will be better and increased the fish body's antibodies [14].

Table 2. Leukocyte of Tilapia (O. niloticus)

\begin{tabular}{cccc}
\hline \multirow{2}{*}{ Doses $(\mathbf{p p m})$ Leukocyte $\left(\times 10^{4}\right.$ cell. $\left.\mathrm{mL}^{-1}\right)$} \\
\cline { 2 - 4 } & Day-0 & Day-3 & Day-6 \\
\hline 0 & $14.23 \pm 0.46^{\mathrm{a}}$ & $14.49 \pm 0.26^{\mathrm{b}}$ & $13.51 \pm 0.34^{\mathrm{a}}$ \\
75 & $14.40 \pm 0.57^{\mathrm{a}}$ & $23.40 \pm 0.36^{\mathrm{c}}$ & $21.32 \pm 0.21^{\mathrm{b}}$ \\
100 & $15.14 \pm 0.09^{\mathrm{a}}$ & $25.54 \pm 0.23^{\mathrm{d}}$ & $23.47 \pm 0.31^{\mathrm{c}}$ \\
125 & $15.40 \pm 0.42^{\mathrm{a}}$ & $27.40 \pm 0.03^{\mathrm{e}}$ & $24.71 \pm 0.12^{\mathrm{d}}$ \\
\hline
\end{tabular}

Notes: Day - is after injected by neem leaves fraction

On day 6 , there was a decrease in the number of leukocytes in the treatment of doses of 75, 100 or $125 \mathrm{ppm}$. This is supposedly the fish's body defense system is working in recognizing the existence of foreign objects that enter the body. In a research explained leukocytes are blood cells that play the role of antibody system functions in the fish body [22]. When the body already recognizes the foreign object, the leukocyte level will decrease indicating that the fish is back to normal condition.

\section{Fraction-4 on Erythrocytes}

The results of observation on erythrocyte values in tilapia during the study increased after the treatment of fraction- 4 neem leaf $(A$. indica A. Juss). Treatment of fraction dose $(75,100$ and $125 \mathrm{ppm}$ ) was significantly different from Control treatment (0) without fraction; where total erythrocyte values increase along with increasing doses (Table 3).

In each treatment of dose fraction- 4 neem leaves (A. indica A. Juss), the erythrocyte level increased compared to Control (0) without fraction. The increase is higher along with the increase of dose fraction of neem leaves ( $A$. indica $\mathrm{A}$. Juss). It is predicted that neem leaves fraction ( $A$. indica) can increase the erythrocyte content after 3 days of administration. Increased levels of erythrocytes are assumed to be an effect from the activity of the neem leaves.

Table 3. Erythrocyte of Tilapia (O. niloticus)

\begin{tabular}{|c|c|c|c|}
\hline \multirow{2}{*}{ Doses (ppm) } & \multicolumn{3}{|c|}{ Erythrocyte ( $\times 10^{5}$ cell. $\mathrm{mL}^{-1}$ ) } \\
\hline & Day-0 & Day-3 & Day-6 \\
\hline 0 & $20.14 \pm 0.51^{\mathrm{a}}$ & $20.27 \pm 0.57^{a}$ & $21.13 \pm 0.55^{a}$ \\
\hline 75 & $20.30 \pm 0.32^{a}$ & $20.80 \pm 0.20^{a}$ & $24.03 \pm 0.49^{b}$ \\
\hline 100 & $19.87 \pm 0.46^{a}$ & $21.87 \pm 0.75^{a}$ & $26.50 \pm 0.75^{c}$ \\
\hline 125 & $20.10 \pm 0.53^{a}$ & $23.10 \pm 0.70^{b}$ & $27.76 \pm 0.66^{c}$ \\
\hline
\end{tabular}

Notes: Day - is after injected by neem leaves fraction 
Terpenoids flavonoids are compounds that capable of increasing erythropoiesis (the process of erythrocyte formation) in the bone marrow [23]. Erythrocyte function is for supplying feeding to cells, tissues, and organs. If the amount of erythrocytes is low then the process of fish metabolism will be hampered [18].

\section{Phytochemical Analysis of Fractions-4 Neem} Leaf ( $A$. indica A. Juss)

Phytochemical tests on the fraction- 4 neem leaf ( $A$. indica A. Juss) included flavonoids, alkaloids, saponins, tannins, terpenoids and polyphenols [23]. The result of phytochemical analysis of fraction-4 neem leaf ( $A$. indica $A$. Juss) ethanol solvent can be seen in Table 4 .

Table 4. Phytochemistry of Neem Leaf (A. indica A. Juss) Fraction 4

\begin{tabular}{lcl}
\hline Phytochemistry & Result & Note \\
\hline Flavonoid & + & Formed pink \\
\hline Alkaloid & & \\
Meyer & - & No white precipitate formed \\
Dragendroff & - & No orange precipitate formed \\
Tannin & - & No color changes \\
Saponin & - & Absence of permanent foam \\
Terpenoid & ++ & Absence of permanent foam \\
Polyphenol & - & No blackish-green color \\
\hline
\end{tabular}

The result of the phytochemical test showed that fraction-4 neem leaf is positively contains 2 compounds namely flavonoids $(+)$, terpenoids $(++)$. It can be concluded that fractionation using Column Chromatography (CC) method can separate the existing compounds from a material simplicia that can be used for subsequent application. The insight on the method of analysis and solvent used on a material will affect the secondary metabolite content produced [24].

FTIR analysis of Fraction 4 leaves of neem ( $A$. indica $A$. Juss)

Results of FTIR spectrophotometric analysis of fraction-4 neem leaves ( $A$. indica $A$. Juss) shows the frequency region as 8 types of bond in a compound. With FTIR spectra patterns, it is shown that fraction-4 contains several functional groups, each of the functional groups provides different absorptions in each specific area. Based on the wavelength obtained, the fraction- 4 of neem leaves contains the dominant functional groups in the spectra $3401.543 \mathrm{~cm}^{-1}$ and $1391.103 \mathrm{~cm}^{-1}$, i.e. carboxylic acid $\left(\mathrm{RCO}_{2} \mathrm{H}\right)$ and alcohol (ROH); spectra 2928.039 which is a $\mathrm{CHO}$ functional group with alkane, aldehine and ketones and spectra $1062.567 \mathrm{~cm}^{-1}(\mathrm{OH})$ which is a hydroxyl functional group. The fraction bands and clusters at fraction- 4 neem leaf can be seen in Table 5.

Table 5. Fraction and Force Absorption Bands in Fraction-4 Neem Leaves

\begin{tabular}{ccccc}
\hline $\begin{array}{c}\text { Bandwidth Numbers and } \\
\text { Compounds }\end{array}$ & $\begin{array}{c}\text { Bandwidth Numbers } \\
\left(\mathbf{c m}^{-\mathbf{1}}\right)\end{array}$ & Cluster & Intensity & Functional Groups \\
\hline $4000-3200$ & 3401.543 & $\begin{array}{c}\mathrm{O}-\mathrm{H} \\
\mathrm{RCO}\end{array}$ & Great widened & $\begin{array}{c}\text { Alcohol (H-bounded) } \\
\text { Carboxylic acid }\end{array}$ \\
\hline $2940-2915$ & 2928.358 & $\mathrm{CHO}$ & medium, sharp & Alkanes, Aldehydes, Ketones \\
\hline $1870-1550$ & 1645.358 & $\mathrm{C}-\mathrm{H}$ Aliphatic & Medium, sharp & Alkanes \\
\hline $1490-1150$ & 1391.103 & $\begin{array}{c}\mathrm{O}-\mathrm{H} \\
\mathrm{RCO}\end{array}$ & Medium, sharp & Carboxylic acid \\
\hline $1090-1020$ & 1062.567 & $\mathrm{OH}$ & Tall, sharp & Hydroxyl \\
\hline
\end{tabular}

Based on the spectra formed on the FTIR test, the fraction-4 neem leaves consists of terpenoids and flavonoids. According to Harborne, terpenoid compounds are compounds containing alcohols, aldehydes, and carboxylic acids, while for flavonoids can be found as mono-, di- or triglycosides in which the hydroxyl $(\mathrm{OH})$ group in the flavonoid molecule is bound by sugar [25].

\section{Gas Chromatography Spectrophotometric Mass} Analysis (GC-MS) Fraction-4 Neem Leaf

The GC-MS analysis is a continuation identification of the FTIR test, which in FTIR test, the compound contained has not been ascertained in the test isolate. The GC-MS analysis aims to measure the type and content of compounds in a sample both qualitatively and quantitatively. GC-MS analysis detected fraction4 neem leaves ( $A$. indica $A$. Juss) contained 10 active compounds. Existing active compounds are identified by comparison of retention time and mass spectrum with library databases (Fig. 3). GC-MS is a method of separation for organic compounds using two methods of analysis, namely Gas Chromatography (GC); to quantitatively analyze of compounds and Mass Spectrometry (MS) to analyze the molecular structure of compounds [26]. The results of the identification are several highly active compounds. Based on the database of MS 
libraries, this compound formed by molecules $\alpha$ Cubebene/Copaene, Caryophyllene, Benzofuranone, Azulene-Cycloprop, Neophytadiene, and Dodecanoic.

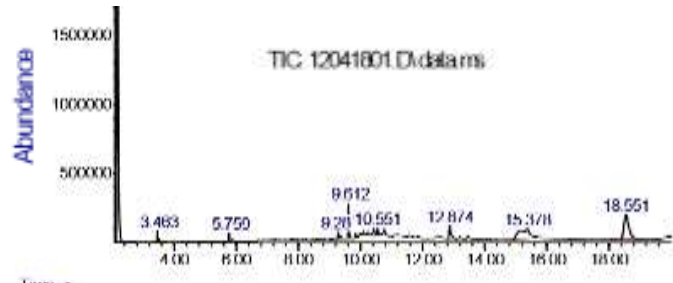

Figure 2. Fraction-4 GC-MS analysis of Neem Leaf ( $A$. indica $\mathrm{A}$. Juss)

The highest content of compound obtained from fraction-4 neem leaves ( $A$. indica $A$. Juss) is formed by terpenoid compounds. It is indicated by the highest peak with 4 terpenoid compounds, 1 flavonoid compound, and 1 lauric acid. The compounds obtained from the GC-MS analysis can be seen in Table 6 .

Table 6. GC-MS analysis of fraction 4 of neem Leaf ( $A$. indica A. Juss)

\begin{tabular}{ll}
\hline Compounds & Groups \\
\hline a-Cubebene/Copaene & Sesqueterpene /Terpenoid \\
Caryophyllene & Sesqueterpene /Terpenoid \\
Benzofuranone & Quercetin /Flavonoid \\
Azulene-Cycloprop & Sesqueterpene /Terpenoid \\
Neophytadiene & Diterpenoid/Terpenoid \\
Octadecanoic acid, & Lauric Acid/Lipid Group \\
Dodecanoic & \\
\hline
\end{tabular}

Terpenoid group compounds and lauric acid flavonoids are organic compounds that are very useful for health as anti-inflammatory, antibacterial, antioxidant, and even as a material to increase endurance. Terpenoid compounds, flavonoids contained in herbs, are capable of destroying the bacterial membrane by destroying the outer membrane of Gram-negative bacteria $[27,28]$.

\section{CONCLUSION}

The fraction-4 neem leaves compounds contains terpenoid, flavonoids, and lauric acid. These compounds are potential as immunostimulant ingredients for tilapia because it can increase the number of erythrocytes and leukocytes, which are parameters for fish health.

\section{REFERENCES}

[1] DJPB-KKP. 2017. Data dan statistik perikanan budidaya nasional 2015 - 2019. Ministry of Fisheries and Marines Affairs. Jakarta.

[2] Labh-Shyam N., R.S. Shubha 2014. Application of immunostimulants as an alternative to vaccines for health management in aquaculture. International J. Fish. Aquat. Stud. 2(1). 153-156.

[3] Thiyagarajan, P., A. Lakshmi-Bhavani, M.G. Ebbie, G. Chandra. 2014. A study on the control of Aeromonas hydrophila infection in the cat fish by medicinal plants. Scholars Acad. J. Biosci. 2(2). 144-150.

[4] Mehana, E.E., H. Arshad, Rahmani, M.A. Salah. 2015. Immunostimulants and fish culture: an overview. Annu. Res. Rev. Biol. 5(6). 477-489.

[5] Anderson, D.P. 2004. Immunostimulants, vaccines, and environmental stressors in aquaculture: NBT assays to show neutrophil activity by these immunomodulators. In: Cruz-Suárez, L.E., D. Ricque-Marie, M.G. Nieto-López, D. Villarreal, U. Scholz, M.González. Avances en Simposium Internacional de Nutrición Acuícola. Hermosillo, Sonora. México.

[6] Jeney, G., G. Yin, L. Ardo, Z. Jeney. 2009. The use of immunostimulating herbs in fish. An overview of research. Fish Physiol. Biochem. 35. 669-676.

[7] Lengka, K., H. Manoppo, M.E.F. Kolopita. 2013. Peningkatan respon imun non spesik ikan mas (Cyprinus carpio L) melalui pemberian bawang putih (Allium Sativum). Jurnal Budidaya Perairan. 1(2). 21-28.

[8] Devajee, D.L., C. Binuramesh, R.D. Michael. 2014. Immunostimulatory effect of water soluble fraction of Nyctanthes arbortristis leaves on the immune response in Oreochromis mossambicus (Peters). Aquac. Res. 45. 1581-1590.

[9] Payung, C.N., H. Manoppo. 2015. Peningkatan respon kebal non-spesifik dan pertumbuhan ikan nila (Oreochromis niloticus) melalui pemberian jahe, Zingiber officinale. Jurnal Budidaya Perairan. 3(1). 11-18.

[10] Asif, M. 2012. Antimicrobial potential of Azadirachta indica against pathogenic bacteria and fungi. J. Pharmacogn. Phytochem. 1(4). 78-83.

[11] Timotius, S.Y., S.Y. Goji, B. Abdussalam, Y. Mava, I.H. Galadima. 2011. Antibacterial and phytochemical screening of the ethanolic leaf extract of Azadirachta Indica (Neem) (Meliaceae). Int. J. Appl. Biol. Pharmaceut. Technol. 2. 194-199.

[12] Rajasekaran, E., V. Meignanam, T. Vijayakumar, S. Kalaivani, N. Ramya, Premkumar, R. Siva, R. Jayakumararaj. 2008. Investigations on antibacterial activity of 
leaf extracts of Azadirachta indica A. Juss (Meliaceae): a traditional medicinal plant of India. Ethnobot. Leaf. 12. 1213-17.

[13] Lamadi, A. 2017. Efektifitas Nannochloropsis sp. terhadap sistem imun non-spesifik ikan mas Cyprinus carpio yang diinfeksi Virus Herpes. Jurnal IImu-Ilmu Perairan, Pesisir dan Perikanan. 6(3). 259-264.

[14] Purwaningsih. 2013. Vaksin koktail sel utuh untuk pencegahan penyakit Mycobacteriosis dan motile Aeromonas septicemia pada ikan gurame (Osphronemus gouramy). Master Thesis. Graduate School, Bogor Agricultural University. Bogor.

[15] Abror, Y.K., D.W. Evy, Suhariyadi. 2018. Immunomodulator of ethanol extracts of the leaves Azadirachta indica against macrophage peritoneal cell in mice induced the vaccine BCG. Jurnal Teknologi Laboratorium. 8(1). 8-14.

[16] Vinoth, B., R. Manivasagaperumal, S. Balamurugan. 2012. Phytochemical analysis and antibacterial activity of Moringa oleifera Lam. Int. J. Res. Biol. Sci. 2(3). 98102.

[17] Bigoniya, P., K. Singh. 2014. Ulcer protective potential of standardized hesperidin, a citrus flavonoid isolated from Citrus sinensis. Rev. Bras. Farma. 24. 330-340.

[18] Harborne, J.B. 2006. Metode fitokimia. penuntun cara modern menganalisis tumbuhan. In: Padmawinata, K. (Transl). Bandung Institute of Technology Publisher. Bandung.

[19] Tyson, J. 1988. Analysis - what analytical chemists do. Royal Society of Chemistry. Cambridge, England.

[20] Murray, R.K., D.K. Gran, P.A. Mayer, V.W. Rodwel. 1996. Biokimia Harper, 24 ${ }^{\text {th }}$ Ed. In: Hartono, A. (Transl). Penerbit Buku Kedokteran EGC. Jakarta.

[21] Anderson DP, Siwicki AK. 1993. Basic hematology and serology for fidh healthprogram. Paper presented in second symposium on diseases in Asian Aqauaculture "Aquatc Animal Healt and the Enviroment" Phuket Thailand 25-29 th Oktober. Oktober 1993;25-29

[22] Murray, R.K., D.K. Gran, P.A. Mayer, dan V.W. Rodwel. 1996. Biokimia Harper, Edisi 24, diterjemahkan oleh Hartono, A. Penerbit Buku Kedokteran EGC. Jakarta.

[23] Saragih, S.P., H. Syawal, M. Rauwaty. 2015. Total of erythrocytes, haematocrit, and haemoglobin changes of Pangasius hypophthalmus that were immersed in curcumin extract and that were in infected by Aeromonas hydrophila. Jurnal Online Mahasiswa (JOM) Bidang Perikanan dan Ilmu Kelautan. 3(2). 1-14.

[24] Wedemeyer, G.A., W.T. Yasutake. 1977. Clinical methods for the assessement of the effect environmental stress on fish health. Technical Papers of The U.S. Fish and Wildfield Service. US. Dept. Interior Fish and Wildlife Service. 89. 1-17.

[25] Biswas, K., I. Chattopadhyay, R.K. Banerjee, U. Bandyopadhyay. 2002. Biological activities and medical properties of Neem (Azadirachta indica). Curr. Sci. 82(11). 13361344.

[26] Zhao, J., L. Ge, W. Xiong, F. Leong, L. Huang, S. Li. 2015. Advanced developments in phytochemicals analysis of medicine and food purposes plants used in China (2011 2014). J. Chromatogr. A. 7. 231-240.

[27] Ragasa, C.Y., P. Tsai, C. Shen. 2009. Antimicrobial terpenoids from Erigeron sumatrensis. NRCP Res. J. 10(1). 27-32.

[28] Makkawi, A.J.J., E.M. Keshk, M.M. ElShamy, M. Abdel-Mogib. 2015. Phytochemical and biological evaluation of Ambrosia maritima. Res. J. Pharmaceut. Biol. Chem. Sci. 6(4). 1678-1688 